\title{
IMPACT OF CARBON TAXES, ECONOMIC GROWTH, GLOBALIZATION, FOREST RENT, INFLATION AND URBANIZATION ON SUSTAINABLE DEVELOPMENT IN CHINA
}

\author{
Dr. Haga Elimam $1 \bowtie$ (iD) \\ ${ }^{1}$ Economics Department, FEA, King Abdulaziz University, Saudi Arabia
}



Received 5 November 2021

Accepted 17 December 2021

Published 31 December 2021

\section{CorrespondingAuthor}

Dr. Haga Elimam,

ana.imam@yahoo.com

DOI

10.29121/granthaalayah.v9.i12.2021 .4450

Funding: This research received no specific grant from any funding agency in the public, commercial, or not-for-profit sectors.

Copyright: (C) 2021 The Author(s). This is an open access article distributed under the terms of the Creative Commons Attribution License, which permits unrestricted use, distribution, and reproduction in any medium, provided the original author and source are credited.

\section{ABSTRACT}

The study's objective was to investigate the impact of carbon taxes, economic growth, globalization, forest rent, inflation, and urbanization on sustainable development in China. The study has used secondary data from World Development Indicators and International Energy Association from 1992 to 2020. For data analysis, the study has employed panel unit root analysis, panel cointegration analysis, Hausman test, and random-effect OLS technique for data analysis. The results showed that forest rent was significantly related to sustainable development. Moreover, the natural logarithm of GDP has negative and urbanization has a positive impact on sustainable development. On the other hand, inflation has an insignificant but negative impact on sustainable development. Also, globalization and carbon taxes have a positive impact on sustainable development. The study concluded that higher carbon taxes have proved to be a boom for sustainable development solutions in China. The results indicated that with the slow and gradual increase in the level of carbon taxes, the emissions of carbon dioxide will be reduced to varying degrees. The study found that among the six variables, carbon taxes have the most significantly strong impact on sustainable development followed by globalization, forest rent, and urbanization whereas gross domestic product and inflation have a negatively significant impact on sustainable development.

Keywords: Carbon Taxes, Economic Growth, Globalization, Forest Rent, Inflation, Urbanization, Sustainable Development

\section{INTRODUCTION}

To prevent worldwide warming to surpass its limits, the worldwide network wishes to elevate the price range for renewable electricity (Shah et al. (2018). From 1977 to 2011, China accomplished an increased price of 17\% representing the simplest $8.8 \%$ of the full electricity made in 2011 . To reap greater sustained monetary increase, China wishes to concentrate on generating clean, cheap and much less depending on different countries (Lin and Moubarak (2014). As per a recent literature review, the emission of carbon dioxide and global warming should be below $2^{\circ} \mathrm{C}$ in 2020 ; otherwise, it would exceed its limits, resulting in undesirable consequences (Shah et al. (2018). Presently, fossil propellants like oil, coal, and natural gases are normally consumed in various parts of the world. Its manufacturing is likewise risky for the environment. 
Most of China is in the developing phase and is rich in natural wind, flowing water, and sunshine, which can meet increasing electricity demand. Still, Afghanistan has failed to utilize these renewable energies as it lacks the technology and uses non-renewable sources to meet its electricity needs Zeb et al. (2014)). Factor restraining investments into renewable energy are the doubt of the returns it will deliver in the future. But, the most important factor that is to be argued here relates to whether the investment in and production of renewable energy will significantly affect oil prices. Some analysts expected the upward push in oil listings had created a debate at the effect of this upward push on renewable investment Shah et al. (2018). The analysis showed a huge amount of knowledge on the direction of causality between carbon taxes and GDP for the conversation measure to create suitable energy policies. The main idea for the discussion of carbon taxes or GDP Magazzino (2016). Along with the labor and capital, technological and economic processes are considered prerequisites for developing the modern energy utilization process. Without GDP, energy and technological processes will be unachievable; the researcher supported revealing the hypothesis Ouyang and Li (2018).

The development of people's dwelling requirements has been substantial. The vital issue of modern energy, specifical power, can't be omitted and for the evolved international countries the improvement of technical era and science. Electricity utilization uplifted the education sector and health, specifically in growing countries for the population Solarin et al. (2016). For the improvement of infrastructure and economy, power usage can't be omitted withinside the present-day era Yang et al. (2016). Besides the research on energy analysis, powerful and dependable infrastructure is the most influential standard for diversification and financial growth. This research contributes significantly to the existing body of literature. Firstly, it investigates the influence of carbon taxes, urbanization, globalization, forest rent, inflation, and economic growth on sustainable development. According to the author's best knowledge, this is the first study that has investigated the impact of the above variables in context with China. Moreover, this study would be useful to explore the relationship between urbanization and sustainable development as urbanization can help to promote economic growth and resource efficiency. That is why de-urbanization is not even an adequate choice even if urbanization degrades the environment. Furthermore, China is not the country with scarce resources, only scarce management, making this country weak. Consequently, it is necessary to control the situation by lifting the level of carbon taxes in China. Lastly, the policymakers surely get the advantage by scrutinizing the research results and working over human and energy development to make China prosperous.

\section{RESEARCH OBJECTIVE}

The study's objective was to investigate the impact of carbon taxes, economic growth, globalization, forest rent, inflation, and urbanization on sustainable development in China.

\section{Research Question}

Question: What is the impact of carbon taxes, economic growth, globalization, forest rent, inflation, and urbanization on sustainable development in China? 


\section{LITERATURE REVIEW}

Gupta et al. (2019) conducted an observation to analyze macroeconomic results of reaching improvement alongside low carbon pathways, we use a hybrid modeling structure that mixes the strengths of the AIM/ Endues bottom-up version of Indian electricity structures and the IMACLIM top-down economy-extensive version of India. This hybrid structure stands upon a unique dataset that reconciles countrywide accounting, electricity stability, and electricity price statistics. With this tool, we exhibit that low-carbon situations can accommodate every year monetary growth of 5.8\% from 2013 to 2050 i.e., carry out near close to if not slightly higher than our business-as-usual scenario, despite high investment costs. This end result in part stems from the development of the Indian trade balance through a good-sized discount on massive fossil gasoline imports.

Countries can achieve sustainable development and ecological sustainability with making enact environmental regulations. Whereas, environmental regulations cannot achieve environmental sustainability until it implemented effectively. Ahmed et al. (2021) study examines the relationship between democracy, environmental regulations, economic growth, and ecological footprint (EF) in the panel of G7 nations from 1985 to 2017. The results show that economic growth enhances ecological footprint while environmental regulations and democracy positively contribute to ecological sustainability by reducing the ecological footprint. A study by Hao et al. (2021) evaluates the role of ecologically calibrated multifactor effective growth (i.e., green growth) in promoting a sustainable environment. The outcomes specify that both the linear and non-linear words for green growth along with environmental tax, renewable energy, and human capital reduce carbon dioxides emission. Both in the long-run and short-run, the impact of GDP growth is environment depletion.

Carbon tax is a type of tax that is imposed on fossil energy based on the emissions of $\mathrm{CO}_{2}$ to decrease or reduce the emission of $\mathrm{CO}_{2}$ and to have control over the excessive use of fossil fuels Jia et al. (2018). Recently, a carbon tax has become an essential means of preventing and controlling the emission of carbon dioxide. Through government initiatives to rectify the externality of the market economy, carbon dioxide emissions can be reduced extensively. By imposing carbon taxes, the increase of cost will force the companies to eradicate the reverse manufacturing procedures and use improved pure energy. While, in contrast, carbon taxes will inspire companies to make large investments in the research and development of technologies focused on the reduction of emissions. Under the combined effect of some of the factors, the economic infrastructure may be adjusted and upgraded, with the improvement of domestic monetary mode modified from conventional huge version to a low-carbon primarily based totally economy Niu et al. (2019).

This inverse-impact of microeconomics on people can sell the transformation of the intake shape of sources even as giving a push to the macroeconomy in the direction of the course of sustainable improvement so that you can cause financial improvement and environmental protection. China being $2^{\text {nd }}$ largest economic core in the world, it is not just the largest developing country but also the one with the largest carbon dioxide excretion. To decrease the emissions from the glasshouse effect, the country's government has put forward the 2030 carbon dioxide emission reduction as an objective, and to achieve the desired goal, China's power industry will be a significant breakthrough point Saint et al. (2020).

A comparative examination in China by Xie et al. (2018) implemented a twolocation dynamic computable general equilibrium (CGE) version to find out how 
differentiated carbon taxes amongst areas might have an effect on the competitiveness of neighborhood industries, taking Chongqing an inland town in China as an example. The findings suggest that once carbon taxes are carried out it lessen the carbon emission and electricity and reap China's Nationally Determined Contribution goal with the aid of using 2030 however, it has bad outcomes in the macroeconomy of China. Meanwhile, Chongqing's industrial competitiveness will be affected heterogeneously. When the carbon tax is higher in Chongqing than in the rest of China, the sectors that benefit from increased output activity are food, agriculture, transport equipment, textile, machinery, and electronics, and those sectors that will suffer the output losses are non-metal production, metal smelting, chemical, and paper. And whilst this take a look at is as compared with the previse study of Xu Tian et al. (2017) to see the variations amongst inland towns like Chongqing, where the financial state is inland oriented, and Shanghai, which is greater export and trade-oriented. It is established that the implementation of the carbon tax will lessen carbon emissions and carbon depth in each Shanghai and Chongqing by 2030, however, it'll have poor outcomes at the financial improvement and commercial competitiveness of each town.

Many governments have implemented carbon taxes to reduce carbon emissions and also provide subsidies for products that consume less energy in production. These governmental rules however enforce the manufacture of such merchandise to emit much less carbon at some stage in the manufacturing system and expand extra power-saving merchandise. An observation selected the producer and store channel wherein the producer has the choice to layout a product to emit much less carbon at some stage in manufacturing and use much less strength while the product is fed on via way of means of the customers. To know that is there any effect of the government's energy-saving products subsidies and carbon taxes. The findings confirmed that the authorities' subsidies have brought on the discount of carbon emission and energy consumptions, however, it isn't always usually authentic for the carbon taxes, authorities have to fee carbon taxes in opposition to manufacturers in keeping with their pollutants levels Yuyin and Jinxi (2018).

Wang et al. (2020) study examines the consequences of financial globalization on environmental degradation (CO2 emissions) for G7 international locations throughout 1996-2017. This research also examines the role of financial development, agriculture value-added, and natural resources in the relationship between economic globalization and $\mathrm{CO} 2$ emissions. The empirical effects of the study indicate that financial globalization, economic development, and natural assets grow carbon emissions. In contrast, agriculture value-delivered decreases carbon emissions.

Destek (2019) conducted a study to examine the effects of various dimensions of globalization, including the economic globalization index, the overall globalization index, the political globalization index, and the social globalization index on the pollution in the environment. For this purpose, they collected data on real gross domestic product and energy consumption in the Central and Eastern European Countries. They collected data for the period ranging from 1995 to 2015 and examined the collected data through second-generation methodologies of panel data to identify the possible cross-sectional dependence in the countries studied. This study showed that the increase in the globalization of the economy, globalization in the social context, and the overall globalization effects enhance carbon emissions.

For those economies that behave vibrant globally, globalization has been playing the role of a driving force. Hassan et al. (2019) conducted a study to investigate natural resources, a globalization factor, on the economy's growth. The 
result also suggests that natural resources also help to increase the level of economic growth. The results of the causality analysis showed that the bidirectional causal effect exists between the usage of natural resources and globalization. The paper suggests policy implications that the nations have to focus on increasing their exports and security and should adopt technological strength.

\section{METHODOLOGY}

Mark et al. (2009) explained two types, including exploratory and explanatory. Exploratory emerges from the root word "Explore", which means to discover something. Therefore, the exploratory studies stress to unleash some phenomenon that either had not been revealed or explored yet or has not gained appropriate attention from the research or practice viewpoint Creswell (2013); Kothari (2004); Mark et al. (2009). However, explanatory research has the root word "Explain," which means describing or elaborating something in a more deliberate and detailed manner. It emphasizes the re-examination of the already known phenomenon but is more elaborative and detailed Creswell (2013); Kothari (2004); Mark et al. (2009). In this regard, the study adequately explained the effect of carbon taxes, economic growth, globalization, forest rent, inflation, and urbanization on sustainable development in China; therefore, it has used explanatory research purposes.

Quantitative research emphasizes dealing with numerical expressions, involving statistical techniques for data assessment and hypothesis-testing standpoint Creswell (2013); Kothari (2004); Mark et al. (2009). On the other hand, qualitative research deals with non-numeric data usually avoid strict inferential statistical techniques and are primarily based on hypothesis development Creswell (2013); Kothari (2004); Mark et al. (2009). In this regard, the current study has used a quantitative research design to emphasize hypothesis-testing and considering numerical data for assessing the phenomenon.

Moreover, the study has used secondary quantitative data gathered from various sources, including the World Bank database of World Development Indicators (WDI) and the International Energy Association (IEA). The study has selected continuous annual data for China from 1992 to 2020 comprised of the past three decades. Following is the consolidated/main statistical equation of the current study.

$$
\mathrm{SD}=(\mathrm{REC})_{i t}+\alpha+\beta_{1}(\mathrm{FR})_{i t}+\sum_{j=2}^{n} \beta_{i} X_{i t}
$$

Where; $\mathrm{X}$ is a set of control variables.

However, the following equation is the detailed version of the equation above.

$$
(\mathrm{SD})_{i t}=\alpha+\beta_{1}(\mathrm{FR})_{i t}+\beta_{2}(\mathrm{GDP})_{i t}+\beta_{3}(\mathrm{GLOB})_{i t}+\beta_{4}(\mathrm{INF})_{i t}+\beta_{5}(\mathrm{Urb})_{i t}+\varepsilon_{i t}
$$

Where; REC is the carbon taxes, FR is the forest rent, GDP is the Gross Domestic Product, URB is the urbanization, INF is the inflation, GLOB is the globalization.

\section{Statistical Techniques}

The study has used different econometrics techniques for data analysis majorly including Panel Unit Root Test for assessing stationarity of the data, Panel Cointegration Test for assessing the existence of the long-run relationship amid the variables, Hausman test for correlated random-fixed effect analysis, and finally, random-effect Panel OLS technique to examine the phenomenon and statistical model of the study. 


\section{RESULTS}

Table 1 provides descriptive statistics of all the variables of the study. The table shows the mean, standard deviation, minimum, maximum values of the observations for each of the variables. All the variables' minimum and maximum values were greater than 1 except that of inflation. The minimum and maximum range of the variables shows how large or small their impact is. The minimum range in the table below is 0.05 which shows the impact of inflation and the maximum range is 108.78 which is that of carbon taxes.

\begin{tabular}{|lccccc}
\hline Table 1 Descriptive Statistics & & & & & \\
\hline Variables & Mean & Std. Dev. & Min. & Max. & Obs. \\
\hline Sustainable development & 45.40 & 2.47 & 1.24 & 84.45 & 208 \\
\hline Log of Gross Domestic Product & 16.33 & 2.84 & 3.47 & 51.02 & 208 \\
\hline Inflation & 24.64 & 6.99 & 0.05 & 38.44 & 208 \\
\hline Carbon taxes & 77.79 & 3.05 & 3.15 & 108.78 & 208 \\
\hline Forest rent & 46.54 & 0.18 & 7.87 & 77.56 & 208 \\
\hline Urbanization & 22.84 & 8.50 & 4.88 & 49.81 & 208 \\
\hline Globalization & 78.69 & 2.83 & 5.88 & 95.99 & 208 \\
\hline
\end{tabular}

Table 2 provides the result of panel unit root analysis. All the variables are nonstationary in levels while being stationary in the first differences therefore all the variables are $I(1)$. After knowing that all the variables are $I(1)$ the study performed a cointegration test to have a look for a continuing connection among the variables, this test is shown in Table 3.

\begin{tabular}{|c|c|c|c|c|c|}
\hline \multicolumn{6}{|c|}{ Table 2 Panel Unit Root Test } \\
\hline \multirow[t]{2}{*}{ Variable } & & \multicolumn{2}{|c|}{ Trend } & \multicolumn{2}{|c|}{ Trend \& Intercept } \\
\hline & & $\mathrm{I}(0)$ & I (1) & $\mathrm{I}(0)$ & I (1) \\
\hline \multirow[t]{3}{*}{ Sustainable development } & LLC & 0.13 & 0.00 & 1.00 & 0.00 \\
\hline & IPS & 0.90 & 0.00 & 0.87 & 0.00 \\
\hline & $\mathrm{ADF}$ & 0.99 & 0.00 & 0.39 & 0.00 \\
\hline \multirow[t]{3}{*}{ Urbanization } & LLC & 0.29 & 0.08 & 0.58 & 0.04 \\
\hline & IPS & 0.99 & 0.00 & 0.74 & 0.07 \\
\hline & $\mathrm{ADF}$ & 0.98 & 0.00 & 0.91 & 0.01 \\
\hline \multirow[t]{3}{*}{ Globalization } & LLC & 1.00 & 0.00 & 1.00 & 0.00 \\
\hline & IPS & 0.10 & 0.00 & 0.58 & 0.00 \\
\hline & $\mathrm{ADF}$ & 0.21 & 0.00 & 0.97 & 0.00 \\
\hline
\end{tabular}




\begin{tabular}{lccccc}
\hline Inflation & LLC & 1.00 & 0.00 & 1.00 & 0.00 \\
& IPS & 0.59 & 0.00 & 0.91 & 0.00 \\
& ADF & 0.88 & 0.00 & 1.00 & 0.00 \\
\hline Log of Gross Domestic Product & LLC & 0.23 & 0.00 & 1.00 & 0.00 \\
& IPS & 0.61 & 0.00 & 0.98 & 0.00 \\
& ADF & 0.89 & 0.00 & 1.00 & 0.00 \\
\hline Carbon taxes & LLC & 0.33 & 0.00 & 1.00 & 0.00 \\
& IPS & 0.77 & 0.00 & 0.99 & 0.00 \\
\hline Forest rent & ADF & 0.33 & 0.00 & 0.00 & 0.00 \\
\hline & LLC & 1.00 & 0.00 & 1.00 & 0.00 \\
\hline & IPS & 0.72 & 0.00 & 0.99 & 0.00 \\
\hline & ADF & 0.82 & 0.00 & 0.61 & 0.00
\end{tabular}

Table 3 shows the results that Carbon taxes, GDP, inflation, and sustainable development have been found non-stationary at a level while found stationary at $1^{\text {st }}$ difference. Henceforth, the study has found statistical applicability of panel cointegration analysis for long-run relationship assessment. Table 3 provides results of Pedroni panel cointegration analysis for assessing long-run relationships among the variables. The table below showed that four out of a total of seven statistics for panel cointegration analysis had been found significant at a $5 \%$ significance level. Therefore, the results have profoundly shown that a long-run relationship exists among cointegrated variables of the model.

\begin{tabular}{|lcc|}
\hline \multicolumn{2}{|c|}{ Table 3 Pedroni (1999) } & Panel Cointegration \\
\hline & Statistics & Prob. \\
\hline Panel v-Statistic & 2.43 & 1.00 \\
\hline Panel rho-Statistic & 3.09 & 1.00 \\
\hline Panel PP-Statistic & 7.76 & 0.02 \\
\hline Panel ADF-Statistic & 4.60 & 0.00 \\
\hline Group rho-Statistic & 6.32 & 1.00 \\
\hline Group PP-Statistic & 4.21 & 0.00 \\
\hline Group ADF-Statistic & 7.15 & 0.00 \\
\hline
\end{tabular}

Level of Significance: $5 \%$

Table 4 provides results and findings for assessing the applicability of fixed or random effect analysis for pooled OLS technique regarding the Hausman test. It has been clearly shown in the table below that cross-section random test statistics have 
been found statistically insignificant at a 90\% confidence interval; therefore, the study has found statistical applicability of random-effect analysis.

\begin{tabular}{|lccc|}
\hline \multicolumn{4}{l}{ Table 4 Hausman Test for Correlated Random-Effect } \\
\hline Test & Chi-Square Statistic & DF & Prob. \\
\hline Cross-section random & 0.00 & 6 & 1.00 \\
\hline
\end{tabular}

Table 5 provides results of random-effect analysis for estimating the relationship between dependent and independent variables. The dependent variable of this study is sustainable development and the rest such as GDP, inflation, carbon taxes, forest rent, globalization, and urbanization are all independent variables. The overall F-value (1026.644) of all the variables reveal that the indivisualistic variables have a important effect on the relying variable.

\begin{tabular}{lcccc}
\hline \multicolumn{2}{l}{ Table 5 Pooled OLS using Random-Effect Method } & & \\
\hline Variable & Coefficient & Std. Error & t-Statistic & Prob. \\
\hline Constant & 181.42 & 49.63 & 3.66 & 0.00 \\
\hline Log of Gross Domestic Product & -6.86 & 1.22 & -5.64 & 0.00 \\
\hline Inflation & 0.10 & 0.04 & 2.26 & 0.02 \\
\hline Carbon taxes & -0.03 & 0.04 & -0.67 & 0.50 \\
\hline Forest rent & 8.19 & 3.62 & 2.26 & 0.02 \\
\hline Urbanization & -10.82 & 0.99 & -10.96 & 0.00 \\
\hline Globalization & 8.54 & 0.23 & 25.87 & 0.00 \\
\hline
\end{tabular}

Dependent Variable: Sustainable development

Adjusted $R$-Square $=0.985 ;$ F-Statistics (Prob.) $=1026.644(0.000)$

Source: Author's Estimation

\section{DISCUSSION}

The objective of the study was to investigate the impact of carbon taxes, economic growth, globalization, forest rent, inflation, and urbanization on sustainable development in China. The results found that forest rent, globalization, carbon taxes, economic growth, urbanization has a positive significant impact on the sustainable development of China, whereas the natural logarithm of GDP has a negative impact on sustainable development. On the other hand, inflation negatively impacted the sustainable development of the country as the consumption shows the transmission of inflation to sustainable development. The result of this study is in line with the findings of a number of studies such as Gupta et al. (2019) who found that countries can attain sustainable development by enacting environmental regulations. Also, Ahmed et al. (2021) found that economic growth enhances sustainable development by reducing the ecological footprint. Moreover, Xie et al. (2018) in his study found that when carbon taxes are imposed it reduces the carbon emission, and strength is attained in China's domestically determined contribution position by 2030 . 
Besides, a study by Yuyin and Jinxi (2018) stated that government subsidies have triggered the reduction of carbon emission and energy consumptions, and carbon taxes are being imposed against companies according to their pollution levels. The study results indicated a positively significant relationship between urbanization and renewable carbon taxes in China. Few previous studies also emphasized the similar viewpoint that due to urbanization, consumption of nonrenewable energy and fossil fuel energy production also increases Beteryeb (2017). However, for economic sustainability and substantial growth, economies have initiated emphasizing and looking for renewable energy ventures Apergis and Payne (2014a), Apergis and Payne (2014b), Apergis and Payne (2015); Beteryeb (2017). To sum it up, the study found that among the six variables, carbon taxes have the most significantly strong impact on sustainable development followed by globalization, forest rent, and urbanization whereas gross domestic product and inflation have a negatively significant impact on sustainable development.

\section{CONCLUSIONS AND IMPLICATIONS}

This research investigated the effect of carbon taxes, economic growth, inflation, globalism, urbanization, and forest rent on sustainable improvement in China. The results stated that carbon taxes have a notable effect on the main source of power supply formation of China's power industry. Moreover, these results indicated that with the slow and gradual increase in the level of carbon taxes, the emissions of carbon dioxide will be reduced to varying degrees. This proves the effectiveness of carbon taxes in the reduction of carbon dioxide emissions. Moreover, the study also found that inflation has a negative impact on sustainable development as high inflation negatively affects sustainable growth by a decrease in the tractions and productions. The consumption reflects the transmission of inflation to sustainable development. Also, the study found a significant impact of forest rent as these units multiplied with the physical quantities extract and determined the rents for each commodity as a share of gross domestic products. An

increase in carbon taxes is not only for countries with low GDP rate but is also for economies with higher GDP as continuous use of non-renewable energies might not affect GDP but it is surely affecting the environment, so economies with good growth rate needs to start investing today in carbon taxes projects to prepare for tomorrow. Lastly, the state should start banning the use of non-renewable energy gradually as leaving this on the market increases the use of non-renewable energies and decreases the launch of renewable energy projects. The increase in the difficulty of the worldwide community means that maintainable evolution should not be labeled by looking at just one perspective or scientific discipline. To plan for maintainable evolution taking the perspective of globalism it is very delicate and complex compared to issues that have been dealt with previously and therefore needs global, cross-country policies and set up global initiatives to coordinate these rules.

Cities have a great influence on people's lifestyles, behaviors, and the consumption pattern of resources therefore, sustainable development is important for not only increasing the liveability in cities but also justifying the environmental problems. That's why the concept of sustainable urban development is associated with urban density, amenities, and infrastructure. The findings of the study would highly contribute towards designing policies focused on sustainable urban growth by helping the government and institutions to start a thought process for a broader and successful implementation of sustainable agenda and then step ahead to one step closer to gain more sustainable outcomes. This approach would help in providing quality, reliability, and performance in achieving sustainable outcomes. 


\section{STUDY LIMITATIONS}

The study was confined to very few variables, so it is advised to add new variables for future research like technological changes, cost renewable energy projects, trade openness, foreign direct investment, and financial development. To test the results for short-run analysis, the Error Correction Method (ECM) could also be used. Future studies can also do a cross-country analysis of developed and developing countries in the same domain.

\section{REFERENCES}

Ahmed, Z., Ahmad, M., Rjoub, H., Kalugina, O. A., \& Hussain, N. (2021). Economic growth, renewable energy consumption, and ecological footprint: Exploring the role of environmental regulations and democracy in sustainable development. Sustainable Development. Retrieved from https://doi.org/10.1002/sd.2251

Apergis, N., \& Payne, J. E. (2014a). The causal dynamics between renewable energy, real GDP, emissions and oil prices: evidence from OECD countries. Applied Economics, 46(36), 4519-4525. Retrieved from https://doi.org/10.1080/00036846.2014.964834

Apergis, N., \& Payne, J. E. (2014b). Renewable energy, output, CO2 emissions, and fossil fuel prices in Central America: Evidence from a nonlinear panel smooth transition vector error correction model. Energy Economics, 42(1), 226-232. Retrieved from https://doi.org/10.1016/j.eneco.2014.01.003

Apergis, N., \& Payne, J. E. (2015). Renewable energy, output, carbon dioxide emissions, and oil prices: evidence from South America. Energy Sources, Part B: Economics, Planning, and Policy, 10(3), 281-287. Retrieved from https://doi.org/10.1080/15567249.2013.853713

Beteryeb, C. N. (2017). The effect of population growth and energy intensity on electricity consumption in Ghana. (Master of Science), Kwame Nkrumah University of Science and Technology, Ashanti, Ghana.

Creswell, J.W. (2013). Research design: Qualitative, quantitative, and mixed methods approaches. UK: Sage publications.

Destek, M.A. (2019). Investigation on the role of economic, social, and political globalization on the environment: Evidence from ceecs. Environmental Science and Pollution Research, 1-14.

Gupta, D., Ghersi, F., Vishwanathan, S. S., \& Garg, A. (2019). Achieving sustainable development in India along low carbon pathways: Macroeconomic assessment. World Development, 123, 104623. Retrieved from https://doi.org/10.1016/j.worlddev.2019.104623

Hao, L. N., Umar, M., Khan, Z., \& Ali, W. (2021). Green growth and low carbon emission in G7 countries: how critical the network of environmental taxes, renewable energy and human capital is? Science of The Total Environment, 752, $141853 . \quad$ Retrieved from https://doi.org/10.1016/j.scitotenv.2020.141853

Hassan, S.T., Xia, E., Huang, J., Khan, N.H., \& Iqbal, K. (2019). Natural resources, globalization, and economic growth: Evidence from Pakistan. Environmental Science and Pollution Research, 1-8. Retrieved from https://doi.org/10.1007/s11356-019-04890-z 
Jia, L., Fan, B. G., Huo, R. P., Li, B., Yao, Y. X., Han, F., ... \& Jin, Y. (2018). Study on quenching hydration reaction kinetics and desulfurization characteristics of magnesium slag. Journal of Cleaner Production, 190, 12-23. Retrieved from https://doi.org/10.1016/j.jclepro.2018.04.150

Kothari, C.R. (2004). Research methodology: Methods and techniques: New Age International.

Lin, B., \& Moubarak, M. (2014). Renewable energy consumption-Economic growth nexus for China. Renewable and Sustainable Energy Reviews, 40(1), 111117. Retrieved from https://doi.org/10.1016/j.rser.2014.07.128

Magazzino, C. (2016). The relationship between co2 emissions, energy consumption, and economic growth in Italy. International Journal of Sustainable Energy, 35(9), 844-857. Retrieved from https://doi.org/10.1080/14786451.2014.953160

Mark, S., Philip, L., \& Adrian, T. (2009). Research methods for business students.

Niu, Y., Liu, S., Gong, Y., Liang, Y., Zhang, X., Yan, B., \& Hui, S. E. (2019). Effects of FGR and changeable combustion parameters and coal/char properties on the formation of ultrafine PMs during pulverized coal char combustion under various 02/N2 and 02/CO2 atmospheres. Combustion Science and Technology, 191(10), 1898-1915. Retrieved from https://doi.org/10.1080/00102202.2018.1539714

Ouyang, Y., \& Li, P. (2018). On the nexus of financial development, economic growth, and energy consumption in china: New perspective from a gmm panel var approach. Energy Economics, 71(1), 238-252. Retrieved from https://doi.org/10.1016/j.eneco.2018.02.015

Saint Akadiri, S., Alola, A. A., Olasehinde-Williams, G., \& Etokakpan, M. U. (2020). The role of electricity consumption, globalization, and economic growth in carbon dioxide emissions and its implications for environmental sustainability targets. Science of The Total Environment, 708, 134653. Retrieved from https://doi.org/10.1016/j.scitotenv.2019.134653

Shah, I. H., Hiles, C., \& Morley, B. (2018). How do oil prices, macroeconomic factors, and policies affect the market for renewable energy? Applied Energy, 215(1), 87-97. Retrieved from https://doi.org/10.1016/j.apenergy.2018.01.084

Solarin, S.A., Shahbaz, M., \& Shahzad, S.J.H. (2016). Revisiting the electricity consumption-economic growth nexus in Angola: The role of exports, imports, and urbanization. International Journal of Energy Economics and Policy, 6(3), 1-26.

Wang, L., Vo, X. V., Shahbaz, M., \& Ak, A. (2020). Globalization and carbon emissions: Is there any role of agriculture value-added, financial development, and natural resource rent in the aftermath of COP21?. Journal of Environmental Management, 268, 110712. Retrieved from https://doi.org/10.1016/j.jenvman.2020.110712

Xie, J., Dai, H., Xie, Y., \& Hong, L. (2018). Effect of a carbon tax on the industrial competitiveness of Chongqing, China. Energy for Sustainable Development, 47, 114-123. Retrieved from https://doi.org/10.1016/j.esd.2018.09.003

Yang, B., Li, Y., Wei, H., \& Lu, H. (2016). Is the urbanization rate a feasible supplemental parameter in forecasting electricity consumption in China? Journal of Engineering, 2016(1), 1-7. Retrieved from https://doi.org/10.1155/2016/2465248 
Yuyin, Y., \& Jinxi, L. (2018). The effect of governmental policies of carbon taxes and energy-saving subsidies on enterprise decisions in a two-echelon supply chain. Journal of Cleaner Production, 181, 675-691. Retrieved from https://doi.org/10.1016/j.jclepro.2018.01.188

Zeb, R., Salar, L., Awan, U., Zaman, K., \& Shahbaz, M. (2014). Causal links between renewable energy, environmental degradation and economic growth in selected SAARC countries: progress towards a green economy. Renewable Energy, $71(1)$ 123-132. Retrieved from https://doi.org/10.1016/j.renene.2014.05.012 